\title{
Evaluation of Intermediary and Mitochondrial Metabolic Responses to 4-nonylphenol in the Freshwater Fish, Labeo Rohita
}

\section{REMYA V S}

University College Thiruvananthapuram

\section{RESHMI S}

University College Thiruvananthapuram

\section{SHEHNA MAHIM S}

University College Thiruvananthapuram

ANJALI V R

University College Thiruvananthapuram

ARUNA DEVI C ( $\nabla$ devinod7@gmail.com )

University College Thiruvananthapuram

\section{Research Article}

Keywords: 4-nonylphenol, Mitochondrial enzymes, Intermediary metabolism, Electron transport system

Posted Date: July 7th, 2021

DOI: https://doi.org/10.21203/rs.3.rs-667820/v1

License: (c) (1) This work is licensed under a Creative Commons Attribution 4.0 International License. Read Full License 


\section{Abstract}

4-Nonylphenol (4-NP) is a breakdown product of nonylphenol ethoxylate (NPE) and attains much concern because of its persistence and toxicity to aquatic organisms. 4-nonylphenol is a known endocrine disruptor and a legendary xenoestrogen. However, non-estrogenic impacts of 4-NP were scarcely studied in aquatic organisms. Hence, the present study evaluated the effects of sublethal concentrations of 4-NP $(1.5,2$ and $2.5 \mu \mathrm{l} / \mathrm{I})$ on major carp, Labeo rohita in the intermediary and mitochondrial metabolism. Exposure to 4-NP shows significant changes in the activities of intermediary enzymes like glucose 6 phosphatase, lactate dehydrogenase, cytosolic malic enzyme and isocitrate dehydrogenase and mitochondrial enzymes like malate dehydrogenase, nicotinamide adenine dinucleotide dehydrogenase, succinate dehydrogenase and cytochrome $c$ oxidase when compared to the control $(p<0.05)$. Therefore, the current study indicates that 4-NP at environment concentration impairs the activity of metabolic enzymes and thereby affects the tricarboxylic acid cycle and electron transport system. Alteration in the levels of these parameters can be effectively used to surveil the impact of 4-NP in energy production in aquatic environment.

\section{Introduction}

Nonylphenol ethoxylate (NPE) is one of the most dangerous chemicals that are recorded in aquatic environments (Tsuda et al. 2000; Rivero et al. 2008). Such chemical is widely used in the production and formulation of many commercially sold products such as industrial and commercial detergents, pesticides, spermicides, paints, wetting agents, textiles, plastics, paper products, polymer resin and cosmetic products (shampoos and deodorants) (Rivero et al. 2008). Due to extensive use of such products and some anthropogenic activities like wastewater treatment, landfilling and sewage sludge recycling, it reaches in to sewage where it is broken down to 4-nonylphenol (4-NP) by microorganisms, which is known to be more stable and persistent (Saito et al. 2004). Due to its low solubility and high hydrophobicity, 4-NP accumulates in these matrices and where it persists (Soares et al. 2008). As it is persistent in the environment, it gets accumulated in aquatic organisms, the concerns regarding the adverse effects of 4-NP has been noticed (Xueji et al. 2017).

4-nonylphenol is a known endocrine-disrupting chemical, due to its ability to mimic or partially mimic naturally occurring estrogen. Hence, 4-NP can compete with estrogen receptor binding and exerts an estrogen-like transcriptional activity on expression of estrogen receptor gene which leads to the overstimulation (Sayad et al. 2012). The upshot of 4-NP on endocrine and reproductive parameter is surveyed in numerous research investigation in fish (Yaron et al. 2003; Choi et al. 2010; Sayed et al. 2012). Fish are used to determine the health of aquatic systems because their biological responses serve as biological markers of environmental pollution. Studies regarding the impact of 4-NP other than its estrogenic effects are rare. From this outlook, it was pondered reasonable to scrutinize the effect of 4-NP on metabolic enzymes in the freshwater fish, Labeo rohita. 
Metabolic enzymes carry out a variety of cellular functions necessary for survival and homeostasis, including proteolysis and digestion, cellular respiration, energy storage, transcription and response to the environment (Lu and Hunter 2018). Since, metabolic enzymes are depicted as proxies for whole animal metabolic capacity and activity (Drazen et al. 2008), further look over into this area is indispensable. Henceforth, this study aimed to investigate the effects of 4-NP on some intermediary enzymes such as glucose 6 phosphatase $\left(\mathrm{G} \mathrm{PO}_{4}\right.$ ase), lactate dehydrogenase (LDH) cytosolic malic enzyme (cME) and isocitrate dehydrogenase (ICDH) and mitochondrial enzymes such as malate dehydrogenase (MDH), nicotinamide adenine dinucleotide (NADH) dehydrogenase, Succinate dehydrogenase (SDH), cytochrome c oxidase (CCO).

\section{Materials And Methods}

\section{Experimental fish}

The animal model, freshwater teleost, L.rohita used in the experiment, having average weight and length of $40 \pm 5 \mathrm{~g}$ and $25 \pm 4 \mathrm{~cm}$ respectively, were collected from local suppliers and brought to the laboratory. The fish were acclimatized for 30 days in dechlorinated tap water. Water temperature $\left(28 \pm 2^{\circ} \mathrm{C}\right)$, oxygen saturation (70-100\%) and $\mathrm{pH}$ (7.6) were properly maintained. Fish were fed ad libitum.

\section{Experimental design and sampling}

4-nonylphenol with $90 \%$ purity was purchased from Himedia, India. The $\mathrm{LC}_{50}$ dose of 4-NP was determined by probit analysis using Organization for Economic Co-operation and Development (OECD) guidelines. Lethal concentration for $50 \%$ mortality $\left(\mathrm{LC}_{50}\right)$ values was determined for $96 \mathrm{hr}$ exposure and was observed to be $3.25 \mu \mathrm{l} / \mathrm{I}$ 4-NP. Based on that, three sublethal concentrations such as $1.5,2$ and $2.5 \mu \mathrm{l} / \mathrm{I}$ of 4-NP were selected for exposure. The sublethal doses of 4-NP was weighed in separate microfuge tubes and dissolved separately by adding about $400 \mu$ l ethanol and diluted to 30 liters of dechlorinated tap water in separate aquarium tanks ( $40 \mathrm{~L}$ ) of dimension $31 \times 41 \times 53 \mathrm{~cm}$. After acclimatization, fish having $40 \pm 5 \mathrm{~g}$ weight were divided into 10 groups of 10 each in separate glass tanks. The fish were exposed to different concentrations of 4-NP with six replicates for each concentration, where maximum 6 fish were used per concentration of the test toxicant. Freshwater sample having the specified doses of 4NP was replaced on alternate days. The first group of fish served as control and was kept in normal

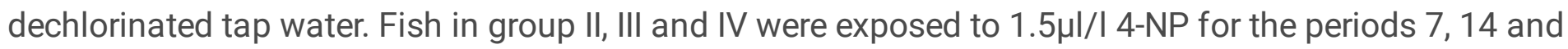
21 days, respectively. Similarly, the groups V, VI and VII were exposed to $2 \mu \mathrm{l} / \mathrm{I}$ of 4-NP and groups of VIII, IX and $\mathrm{X}$ were exposed to $2.5 \mu \mathrm{l} / \mathrm{I}$ 4-NP for 7, 14 and 21 days, respectively. After the above said periods of exposure, fish were sacrificed and $100 \mathrm{mg}$ hepatic tissues were dissected from the body of the fish and kept frozen at $-20^{\circ} \mathrm{C}$ in deep freezer (ROTEK) for further analysis.

\section{ASSAY OF INTERMEDIARY ENZYMES}


Chilled liver was separately homogenized at $4^{0} \mathrm{C}$ in $0.25 \mathrm{ml} \mathrm{SET}$ buffer (sucrose, ethylene diamine tetraaceticacid (EDTA), tris buffer; $\mathrm{pH}$ 7.4) for the intermediary enzyme assay. Homogenates were centrifuged at $2000 \mathrm{rpm}$ at $4^{0} \mathrm{C}$ for $10 \mathrm{~min}$ in a high-speed refrigerated centrifuge (Eppendorf, Germany). The supernatant collected was used as enzyme source. All the enzymes were assayed spectophotometrically (Perkin Elmer, USA) at room temperature.

\section{Glucose 6 Phosphatase (G $6 \mathrm{PO}_{4}$ ase; D-Glucose-6-Phosphatase Phosphohydrolase; E.C.3.1.3.9)}

The activity was assayed by the method of Swanson (1955). Two test tubes, labelled test and control, containing assay mixture of $0.3 \mathrm{ml}$ of citrate buffer $(\mathrm{pH} \mathrm{6.5)}$ and $0.2 \mathrm{ml}$ of glucose-6-phosphate $(\mathrm{pH} 6.5)$ were pre-incubated for $5 \mathrm{~min}$. After mixing the content, $0.1 \mathrm{ml}$ tissue extract was added to the test. Both test tubes were incubated for $15 \mathrm{~min}$ at room temperature and the reaction was arrested by adding $1 \mathrm{ml}$ of $10 \%$ trichloroacetic acid (TCA). After adding $0.1 \mathrm{ml}$ tissue extract to the control, both the test and control were centrifuged for $10 \mathrm{~min}$ at $3000 \mathrm{rpm}$. Supernatant was collected and analyzed for inorganic phosphate by the method of Fiske and Subbarow, (1925). The absorbance was measured at $640 \mathrm{~nm}$ in UV visible spectrophotometer and the activity was expressed as $n$ moles inorganic phosphate liberated/min/mg protein.

\section{Lactate Dehydrogenase (LDH; E.C.1.1.27)}

Lactate dehydrogenase was evaluated according to the protocol of King (1965). The reaction mixture containing the fixed amount of tissue homogenate and NADH solution were pre-incubated in a water bath at $37^{\circ} \mathrm{C}$ for $3 \mathrm{~min}$. The reaction was started by adding $1 \mathrm{ml}$ sodium pyruvate solution and incubated for $30 \mathrm{~min}$. Then, the reaction was stopped by adding $1 \mathrm{ml}$ of 2, 4-dinitrophenylhydrazine and allowed to stand at room temperature for $20 \mathrm{~min}$. After the incubation, $10 \mathrm{ml}$ of $\mathrm{NaOH}$ (sodium hydroxide) was added to each test tube and allowed it to stand for 5 to $10 \mathrm{~min}$. Read the absorbance at $550 \mathrm{~nm}$ by setting the spectrophotometer to zero with distilled water. The specific activity of the enzyme was expressed as $\mathrm{IU} / \mathrm{min} / \mathrm{mg}$ protein.

\section{Cytosolic Malic Enzyme (cME; L-Malate: NADP+ Oxidoreductase; E.C.1.1.1.40)}

The activity of cME was determined by the protocol of Ochoa (1955a). The reaction mixture in a quartz cell $(\mathrm{d}=1 \mathrm{~cm})$ contained $300 \mathrm{ml}$ glycylglycine buffer, $100 \mathrm{ml} \mathrm{MnCl} 2$ and $200 \mathrm{ml}$ of L- malate. The aliquot was made up to $3 \mathrm{ml}$ by double distilled water. One hundred microliter tissue homogenate containing enzyme was added to the reaction mixture. The reaction was started by the addition of $\mathrm{NADP}^{+}$and the change in absorbance was noted at $340 \mathrm{~nm}$ against a blank containing all components except NADP ${ }^{+}$, at intervals of $15 \mathrm{sec}$ for $2 \mathrm{~min}$ and the activity was represented as $\mathrm{IU} / \mathrm{min} / \mathrm{mg}$ protein.

\section{Isocitrate Dehydrogenase (ICDH; Isocitrate dehydrogenase NADP+; E.C.1.1.1.42)}

The enzyme activity was investigated by the protocol of Ochoa (1955b). The reaction mixture in a quartz cell $(\mathrm{d}=1 \mathrm{~cm})$ consisted of $300 \mathrm{ml}$ glycylglycine buffer, $100 \mathrm{ml} \mathrm{MnCl}$ and $200 \mathrm{ml} \mathrm{DL-isocitrate.} \mathrm{The} \mathrm{aliquot}$ 
was made up to $2.8 \mathrm{ml}$ by adding double distilled water. One hundred microliter tissue homogenate containing enzyme was added to the reaction mixture. The reaction was started by the addition of 100 microliter $\mathrm{NADP}^{+}$and the change in absorbance was noted at $340 \mathrm{~nm}$ for $2 \mathrm{~min}$ and the activity represented as $1 \mathrm{U} / \mathrm{min} / \mathrm{mg}$ protein.

\section{ISOLATION OF MITOCHONDRIA AND ASSAY OF MITOCHONDRIAL ENZYMES}

Isolation of mitochondria from liver was carried out according to the method prescribed by Irving and Watson (1976). Chilled liver was weighed and washed several times in SET buffer (0.25M sucrose solution containing $1 \mathrm{mM}$ EDTA, $20 \mathrm{mM}$ tris $\mathrm{HCl}(\mathrm{pH}$ 7.2). Then liver was homogenized in 10 volume (w/v) SET buffer. The homogenate was centrifuged at $600 \mathrm{rpm}$ for $10 \mathrm{~min}$ and the precipitate was discarded in order to remove the nucleus and cell debris. The supernatant was re-centrifuged at $12,000 \mathrm{rpm}$ for $10 \mathrm{~min}$ and the pellet was dissolved in the homogenizing buffer and was used as enzyme source for mitochondrial enzyme assay

\section{Malate Dehydrogenase (MDH; Malate: NAD+ Oxidoreductase; E.C.1.1.1.37).}

The activity of MDH was determined by the method of Mehler et al. (1948). The reaction mixture in a quartz cell $(\mathrm{d}=1 \mathrm{~cm})$ contained $300 \mu \mathrm{l}$ glycylglycine buffer and $25 \mu \mathrm{l}$ of oxaloacetate. The aliquot was made up to $2.8 \mathrm{ml}$ by adding double distilled water. One hundred microlitre tissue homogenate containing enzyme was added to the reaction mixture. The reaction was started by the addition of NADH and the change in absorbance was noted at $340 \mathrm{~nm}$ in a UV visible spectrophotometer against a blank containing all components except $\mathrm{NADH}$, at intervals of $15 \mathrm{sec}$ for $1 \mathrm{~min}$ and the activity represented as $1 \mathrm{U} / \mathrm{min} / \mathrm{mg}$ protein.

\section{NADH Dehydrogenase (E.C. 1.6.5.11)}

The activity of NADH dehydrogenase was measured according to the method of Minakami et al. (1962). The reaction mixture contained $1.0 \mathrm{ml}$ of phosphate buffer, $0.1 \mathrm{ml}$ of potassium ferricyanide, $0.1 \mathrm{ml}$ of nicotinamide adenine dinucleotide (NADH) and $0.2 \mathrm{ml}$ of mitochondrial suspension. The total volume was made up to $3 \mathrm{ml}$ with double distilled water. Nicotinamide adenine dinucleotide was added just before the addition of the enzyme. A control was also treated similarly without NADH. The change in optical density (OD) was measured at $420 \mathrm{~nm}$ as a function of time for $3 \mathrm{~min}$ at an interval of $15 \mathrm{sec}$ in a UV visible spectrophotometer. The activity of NADH dehydrogenase was expressed as $n$ moles of NADH oxidized/min/mg protein.

\section{Succinate dehydrogenase (SDH; Succinate ubiquinone oxidoreductase; E.C.1.3.5.1)}

The activity of SDH was assayed according to the protocol of Slater and Bonner (1952). The reaction mixture containing $1 \mathrm{ml}$ phosphate buffer, $0.1 \mathrm{ml} \mathrm{BSA}, 0.3 \mathrm{ml}$ sodium succinate and $0.2 \mathrm{ml}$ potassium ferric cyanide were made up to $2.8 \mathrm{ml}$ with double distilled water. The reaction was started by the addition of 
$0.2 \mathrm{ml}$ of mitochondrial suspension. The change in OD was recorded at an interval of $15 \mathrm{sec}$ for $5 \mathrm{~min}$ at $420 \mathrm{~nm}$. The SDH activity was expressed as $\mathrm{n}$ moles of succinate oxidized/min/mg protein.

\section{Cytochrome c oxidase (CCO; E.C. 1.9.3.1)}

Cytochrome c oxidase activity was assessed by the method of Pearl et al. (1963). The reaction mixture contained $1.0 \mathrm{ml}$ of phosphate buffer, $0.2 \mathrm{ml}$ of $\mathrm{N}$-phenyl-P-phenylene diamine, $0.1 \mathrm{ml}$ of $0.01 \%$ cytochrome c and $0.5 \mathrm{ml}$ of water. The sample was incubated at $25^{\circ} \mathrm{C}$ for $5 \mathrm{~min} .0 .2 \mathrm{ml}$ of the enzyme preparation was added and the change in OD was recorded at $550 \mathrm{~nm}$ for $5 \mathrm{~min}$ at an interval of $15 \mathrm{sec}$ each in a UV visible spectrophotometer. A control containing all reagents except cytochrome $\mathrm{c}$ was also proceeded in the same manner. The activity of CCO was expressed as $\mathrm{n} g$ atom $\mathrm{O}_{2}$ consumed $/ \mathrm{min} / \mathrm{mg}$ protein.

\section{Estimation of Protein}

Protein concentration was assessed according to the protocol of Bradford (1976).

\section{Statistical analysis}

Statistical analysis was performed by one way analysis of variance (ANOVA) followed by Duncan's (1955) Multiple Range Test using SPSS software. Differences were considered to be significant at $p<0.05$ against control group.

\section{Results}

\section{Activity of intermediary enzymes}

The activity of $\mathrm{G} \mathrm{PO}_{4}$ ase in L.rohita exposed to 4-NP for 7, 14 and 21 days is shown in Fig.1. A significant depletion in $\mathrm{G} 6 \mathrm{PO}_{4}$ ase activity was observed in all exposure groups exposed to 1.5, 2 and 2.5 $\mathrm{\mu l} / \mathrm{I}$ of 4-NP with respect to control. The effect of sublethal doses of 4-NP in LDH activity was determined in the hepatic tissue of L.rohita and the result is given in Fig.2. The activity of LDH decreased significantly in all treatment groups exposed to all sublethal doses $(1.5,2$ and $2.5 \mu \mathrm{l} / \mathrm{I})$ of 4 -NP after 7,14 and 21 days of exposure. The activity of $\mathrm{CME}$ in fish is plotted in Fig.3. There was a significant increment in CME activity in all treatment groups exposed to $1.5,2$ and $2.5 \mu \mathrm{l} / \mathrm{l}$ of 4 -NP after 7,14 and 21 days of exposure with respect to the control. The ICDH activity showed a significant decrement in time dependent manner when exposed to 1.5 and $2.5 \mu \mathrm{l} / \mathrm{l}$ of 4 -NP, with respect to control (Fig.4). Further, a significant decrease was observed in all treatment group exposed to $2 \mu \mathrm{l} / \mathrm{l}$ 4-NP (Fig.4).

\section{Activity of mitochondrial enzymes}

The activity of MDH depleted significantly in all treatment groups exposed to $1.5,2$ and $2.5 \mu \mathrm{l} / \mathrm{l}$ 4-NP except in 7 days treatment group exposed to $2 \mu \mathrm{l} / \mathrm{l} 4-\mathrm{NP}$, where no significant change was noticed (Fig. 5). The effect on NADH dehydrogenase in fish exposed to 4-NP is shown in Fig.6. There was a sharp increase in NADH dehydrogenase activity in 7 and 14 days treatment groups after exposure to 1.5, 2 and 
2.5 $\mu \mathrm{l} / \mathrm{l}$ of 4-NP. However, a significant decrease was observed in 21 days treatment group exposed to 1.5, 2 and $2.5 \mu \mathrm{l} / \mathrm{l}$ 4-NP when compared to 7 and 14 days exposure groups.

A significant increase in the activity of SDH was observed in all exposure groups exposed to 1.5, 2 and $2.5 \mu \mathrm{l} / \mathrm{l}$ 4-NP, though the increase was found to be time dependent in the test groups exposed to 2.5 $\mathrm{l} / \mathrm{l}$ 4-NP (Fig.7). The effect of sublethal doses of 4-NP in CCO activity was determined in the hepatic tissue of fish and the result is given in Fig.8. The CCO activity was found to be significantly decreased in all exposure groups exposed to $1.5 \mu \mathrm{l} / \mathrm{l} 4-\mathrm{NP}$ in a time dependent manner. A significant increase in CCO

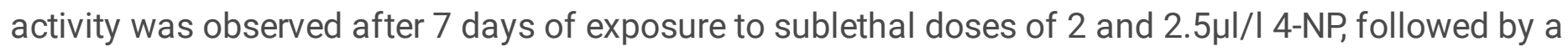
significant decrease in 14 and 21 days exposure groups with respect to the control.

\section{Discussion}

4-nonylphenol is one of the major xenobiotics that exist in nature, mainly in aquatic system (Rivero et al. 2008). According to Kumari et al. (2011), xenobiotics probably induced inhibition or acceleration of whole enzyme system by either changing the enzyme activity or the biochemical processes or by directly affecting the enzyme molecule. Any variations in the respiratory enzyme activities are considered as an early biomarker to access the extent of pollution in the exposed organisms (Chinni et al. 2002). The present study focused on the influence of 4-NP on some metabolic enzymes in intermediary and mitochondrial pathways in the hepatocytes of L. rohita.

The activity of the $\mathrm{G} 6 \mathrm{PO}_{4}$ ase was found to be significantly reduced after exposure to 4-NP. The main function of $\mathrm{G} \mathrm{PO}_{4}$ ase is to contribute free glucose to the blood from liver glycogen pool and some other precursors of glucose 6 phosphate. It also catalyses a critical step in gluconeogenesis and also regulates glucose homeostasis (Mevorach et al. 1998). The $\mathrm{G} \mathrm{PO}_{4}$ ase activity was found to be decreased significantly in Aplocheilus lineatus (valenciennes) on exposure to glyphosate (Anjali and Aruna Devi 2017) and in Oreochromis mossambicus exposed to bisphenol S (Anjali et al. 2021). The significant decrease in $\mathrm{G} \mathrm{PO}_{4}$ ase activity was also reported in Mystus vittatus on exposure to metasystox and sevin

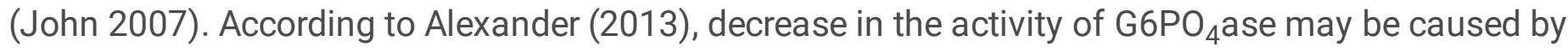
microsomal membrane damage as this enzyme is distributed exclusively in the membranes of the endoplasmic reticulum. In the present investigation, the decreased activity of $\mathrm{G} \mathrm{PO}_{4}$ ase in L. rohita may interfere with the balance between glucose storage and glucose production and may also affect glucose homeostasis (Zhang et al. 2019).

In the current study, the activity of LDH was found to be significantly decreased in fish exposed to 4-NP. Lactate dehydrogenase catalyses the reversible conversion of lactate to pyruvate and vice versa. The literatures in concern with the adverse effects of 4-NP or its allies on the LDH activity of fishes are rare but there are many studies about the effects of other chemical pollutants on these enzyme (Mekkawy et al. 2010a). Amali (1995) has reported a significant decrement in LDH activity in the tissues of L. rohita in response to quinolphos, padan and their mixture. A significant decrease in LDH activity was also observed in Nile tilapia, Oreochromis niloticus exposed to cadmium (Elumalai et al. 2001), in Channa 
punctatus after exposure to mercuric chloride (Almeida et al. 2001) and monocrotophos (Ncibi et al. 2008), in O. mossambicus exposed to bisphenol S (Anjali et al. 2021). Lactate dehydrogenase is generally associated with cellular metabolic activity and hence, its inhibition may be due to ion imbalance or plasma membrane damage (Sastry and Gupta 1980) and may also be due to the formation of enzyme inhibitor complex (Singh and Sharma 1998). Thus, the significant changes in enzymes activity of LDH indicate damage to any or all organs producing this enzyme (Young et al. 1999). Changes in LDH activity may provide direct and indirect evidence of the cellular damage and can indicate the toxic mechanism (Young et al. 1999). The present investigation reveals that the decrease in LDH activity leads the tissue respiratory metabolism towards anaerobic glycolysis (Almeida et al. 2001). Furthermore, the decreased activity of LDH in L.rohita may be due to the interference of 4-NP with energy metabolism.

The activity of the cME in the liver showed significant increase due to sublethal exposure to 4-NP. Cytosolic malic enzyme is involved in catalyzing the NADPH production for reductive fatty acid biosynthesis and also catalyses the reversible decarboxylation of malate to form pyruvate in the presence of NADP coenzyme. This enzyme is particularly interesting since it uses pyruvate as a substrate and provides an alternative route for pyruvate metabolism in fish during the active mobilization of protein as an energy source or supports gluconeogenesis in the liver (Mommsen 2004). Malic enzyme activity has an important role in complete oxidation of intermediate compounds in tricarboxilic acid (TCA) cycle for energy production (McKenna et al. 1995). A significant increase in the activity of cME was reported in $A$. lineatus after exposure to glyphosate (Anjali and Aruna Devi 2017) and in O. mossambicus exposed to bisphenol S (Anjali et al. 2021). The present study indicated that increase in cME activity oxidizes malate rapidly which might lead to accelerated reduction of malate in cells and thereby disturbs redox status in fish.

In the present study, 4-NP exposure significantly reduced ICDH activity. Isocitrate dehydrogenase is a key enzyme which catalyses the reversible oxidation of isocitrate to oxalosuccinic acid, followed by decarboxylation, leading to the formation of alpha keto glutarate. Isocitrate dehydrogenase is found only in the mitochondrion and this enzyme appears to participate in the TCA cycle. On the view point of Benderdour et al. (2004), because of its role in intermediary metabolism and energy production, ICDH has been extensively studied with respect to its isoenzymes, regulation, kinetics, and its presence in other species including prokaryotes. The significant reduction in the activity of ICDH was observed in common carp, Cyprinus carpio on exposure to cadmium (Ivanina et al. 2008), in Larimichthys croceus exposed to copper (Meng et al. 2016), in A. lineatus exposed to glyphosate (Anjali and Aruna Devi, 2017) and in $O$. mossambicus exposed to bisphenol S (Anjali et al. 2021). The reduced activity of ICDH indicated that, 4NP exposure in fish may influence energy and redox status. It may lead to an interruption of steroidregulated cellular and physiological process in fish considering that steroid hormones are known to produce variation in fish intermediary metabolism (Sunny et al. 2003). The reduced ICDH level might inhibit the activation energy of mitochondrial metabolism and thereby it may lead to diminished ATP synthesis by oxidative phosphorylation uncoupling. 
Malate dehydrogenase activity was significantly decreased when the fish was exposed to sublethal doses of 4-NP. Malate dehydrogenase is an enzyme that reversibly catalyses the oxidation of malate to oxaloacetate. This reaction is a part of many metabolic pathways, including the citric acid cycle. Several studies are done related to the significant decrease in activities of TCA cycle enzymes to the changes in the integrity of mitochondria (Tiwari and Singh 2009; Anjali and Aruna Devi 2017; Anjali et al. 2021). The significant decrement in activity of MDH was observed in matrinxa, Brycon cephalus exposed to Folidol 600 (Archanakumta et al. 1998), in L. rohita on exposure to endosulfan (Suneetha 2012) and cypermethrin (Tiwari et al. 2012) and in O. mossambicus exposed to bisphenol S (Anjali et al. 2021). The decreased level of MDH activity may lower the level of functioning of Krebs cycle due to inadequate supply of substrate or decreased oxygen uptake at the tissue level during toxicity stress (Tiwari and Singh 2009).

The activity of NADH dehydrogenase increased significantly in L. rohita exposed to sublethal doses of 4NP. NADH dehydrogenase is the first enzyme complex in the respiratory chain for generation of ATP by mobilizing cytosolic NADH to mitochondria (Sazanov 2014). Significantly elevated activity of NADH dehydrogenase was reported in grass shrimp, Palaemonetes pugio (Brouwer et al. 2008), in Danio rerio (Martinovic et al. 2009) and in Mytilus galloprovincialis (Woo et al. 2013) exposed to hypoxia. In an anaerobic condition, vast amount of NADH was produced by anaerobic respiration (Tello et al. 2011). The excess amount of NADH is oxidized by the mitochondrial respiratory chain through NADH dehydrogenase distributed on the inner mitochondrial membrane (Davidson and Schiestl 2001). Enhanced activity of $\mathrm{NADH}$ dehydrogenase may be due to the switching of aerobic metabolism to anaerobic pathway (Tello et al. 2011). The increase in the activity of NADH dehydrogenase in the present study might also lead to the imbalance of mitochondrial electron transfer activities and ATP synthesis.

A significant increase in SDH activity was noticed in fish after exposure to 4-NP. Succinate dehydrogenase is an important enzyme of citric acid cycle and catalyzes the reversible oxidation of succinate to fumarate. Succinate dehydrogenase is a primary enzyme in the oxidative catabolism of sugars and is used effectively as a marker of mitochondrial activity (Hosetti et al. 2011). The significant elevation in the level of SDH was observed in Cirrhina mrigala exposed to diethyl phthalate (Nivedita et al. 2002) and in L.rohita on exposure to hexavalent chromium (Jiang et al. 2014). It clearly indicated that the stress produced by a prejudicial effect on energy metabolism causes the increased SDH activity (Jiang et al. 2014).

From the present study, the activity of CCO decreased significantly after exposure to 4-NP. Cytochrome c oxidase activity has been shown to reflect the aerobic metabolic rates of many tissues and whole organisms, and its use as a metabolic indicator in animals has been suggested by Gagnon and Holdway (1999). Cytochrome c oxidase is one of the important enzyme complexes of mitochondrial oxidative phosphorylation system. It is the terminal enzyme of the electron transport system and is distributed in the inner membrane of the mitochondria. This enzyme is also considered as a reliable indicator of metabolic capacity in fish (Pelletier et al. 1994). The significant decrease in CCO activity was also observed in wild yellow perch exposed to cadmium contaminated water (Pierron et al. 2009), in L. rohita 
exposed to cypermethrin (Tiwari et al. 2012), in O. mossambicus in response to octylphenol (Sreedevi and Chitra 2014), in A. lineatus exposed to glyphosate (Anjali and Aruna Devi 2017) and in 0. mossambicus exposed to bisphenol S (Anjali et al. 2021). The significant inhibition of CCO by 4-NP in the present study, suggested that the oxidative metabolism of exposed fish might have been altered due to the reduced capacity of the electron transport system (ETS) to produce ATP molecules (Corbett et al. 1984). Hence, 4-NP can be considered as an uncoupler of oxidative phosphorylation which results in reduced synthesis of ATP.

Based on the present study, it was found that 4-NP hindered intermediary and mitochondrial metabolism in the experimental fish. In the current investigation, decreased activities of $\mathrm{G} \mathrm{PPO}_{4}$ ase, $\mathrm{LDH}$ and ICDH and increased cME activity disrupted the intermediary metabolism. Similarly, it was observed that 4-NP interfered the electron transfer chain by decreasing the activities of $\mathrm{MDH}$ and $\mathrm{CCO}$, while increasing the activities of NADH dehydrogenase and SDH activity which might have an impact on an organism's ability to obtain energy by the way of ATP production and oxygen consumption. Several authors (Rao et al. 2003; Vutukuru 2005; Vineet Kumar et al. 2008) have reported that the disturbance in oxidative metabolism lead to alteration in the whole animal oxygen consumption in different species of fish.

\section{Conclusion}

From the present study, 4-NP exhibits a non-estrogenic effects on both intermediary and mitochondrial metabolism. Alteration in metabolic enzyme activities indicated that 4-NP can interfere with both TCA cycle and oxidative phosphorylation which lead to impaired ATP production. 4-nonylphenol can be regarded as an uncoupler of oxidative phosphorylation which inhibits energy production by suppressing ATP synthesis which leads to shifting aerobic pathway of fish respiration towards anaerobic pathway. In conclusion, the persistence of 4-NP in the environment is a serious threat to the aquatic organisms, especially fish and thereby affects the ecological balance.

\section{Declarations}

\section{CONFLICT OF INTEREST}

The authors declare that they have no conflict of interest.

\section{FUNDING STATEMENT}

The present work is not supported by any funding organization.

\section{DATA AVAILABILITY STATEMENT}

Not applicable.

\section{AUTHOR CONTRIBUTIONS}


Remya V S : Conceptualization, Methodology, Validation, Formal analysis, Investigation, Resources, Data curation, Writing-Original draft, Software, Writing-Review and editing, Visualization, Project administration, Funding acquisition.

Reshmi S : Investigation, Recourses.

Shehna Mahim S : : Investigation, Recourses.

Anjali V R : : Investigation, Recourses.

Aruna Devi C : Conceptualization, Methodology, Validation, Resources, Writing- Review and editing, Supervision, Project administration.

\section{ETHICAL APPROVAL}

Not applicable.

\section{ACKNOWLEDGEMENT}

We acknowledge the laboratory facilities of University College, Thiruvananthapuram and financial support from UGC (University Grand Commission) New Delhi, India.

\section{References}

Alexander A (2013) Evaluation of changes in metabolic parameters and enzymes involved in metabolic pathways in Clarias batrachus after exposure to phenolic compounds. Asian J Biomed Pharm Sci 3:6067.

Almeida JA, Novelli ELB, Silva MD, Pand Junior RA (2001) Environmental cadmium exposure and metabolic responses of the Nile tilapia, Oreochromis niloticus. Environ Pollut 114:169-175. https://doi.org/10.1016/S0269-7491(00)00221-9.

Amali AA (1995) Biochemical and enzymological studies on the toxicity of pesticides (Quinolphos and padan) in the freshwater fish, Labeo rohita (HAM). Ph.D. Thesis, University of Madras. Tamil Nadu, India.

Anjali VR, Aruna Devi C (2017) Impact of glyphosate on intermediary and mitochondrial metabolism on a freshwater fish, Aplocheilus lineatus (valenciennes). J Aquat Biol 5:27-35.

Anjali VR, Shehna Mahim S, Reshmi S, Remya VS, Aruna Devi C (2021) Bisphenol S induced metabolic disruption in a freshwater fish, Oreochromis Mossambicus. J Aquat Biol 9:68-75.

Archanakumta A, Gaikwad SA (1998) Effect of nitrite on succinic dehydrogenase (SDH) and lactic dehydrogenase (LDH) in freshwater fish, Gambusia affinis. Pollut Res 17:177-179. 
Benderdour M, Charron G, Comk B, Ayoub R, Beaundry D, Foisy S, de Blois D, Des Rosier C (2004) Decreased cardiac mitochondrial $\mathrm{NADP}^{+}$isocitric dehydrogenase activity and expression:a marker of oxidative stress in hypertrophy development. Am J Physiol-Heart C 287(5):122-

133. https://doi.10.1152/ajpheart.00378.2004.

Bradford MM (1976) A rapid and sensitive method for the quantitation of microgram quantities of protein utilizing the principle of protein- dye binding. Anal Biochem 72: 248-254. https://doi.org/10.1016/00032697 (76)90527-3.

Brouwer M, Brown-Peterson NJ, Hoexum-Brouwer T, Manning S, Denslow N (2008) Changes in mitochondrial gene and protein expression in grass shrimp, Palaemonetes pugio, exposed to chronic hypoxia. Mar Environ Res 66:143-145.

Chinni S, Khan RN, Yalla-Pragala PR (2002) Acute toxicity of lead on tolerance, oxygen consumption, ammonia-N excretion, and metal accumulation in Penaeus indicus post larvae. Ecotoxicol Environ Saf 51:79-84.

Choi S, Lee CH, Park W, Kim DJ, Sohn YC (2010) Effects of shortened photoperiod on gonadotropinreleasing hormone, gonadotropin, and vitellogenin gene expression associated with ovarian maturation in rainbow trout. Zool Sci 27:24-32.

Corbett JR, Wright K, Baillie AC (1984) The biochemical mode of action of pesticides, $2^{\text {nd }}$ ed. Academic Press, London, 1- 49.

Davidson JF, Schiestl RH (2001) Mitochondrial respiratory electron carriers are involved in oxidative stress during heat stress in Saccharomyces cerevisiae. Mol Cell Biol 21:8483-8489.

Drazen JC, Popp BN, Choy CA, Clemente T, De Forest L, Smith KL (2008) Bypassing the abyssal benthic food web: Macrourid diet in the eastern North Pacific inferred from stomach content and stable isotopes analyses. Limnol Oceanogr 53:2644-2654. https://doi:10.4319/lo.2008.53.6.2644.

Duncan DB (1955) Multiple Range and Multiple F Tests. Biometrics 11:1-42.

Elumalai M, Antunes C, Guilhermino L (2001) Effects of single metals and their mixtures on selected enzymes of Carcinus moenas. Water Air Soil Pollut 141:273-280.

https://doi.org/10.1023/A:1021352212089.

Fiske $\mathrm{CH}$, Subbarow Y (1925) The colorimetric determination of phosphorous. J Biol Chem 66: 375-400.

Gagnon MM, Holdway DA (1999) Metabolic enzyme activities in fish gills as biomarkers of exposure to petroleum hydrocarbons. Ecotoxicol Environ Saf 44:92-99.

Hosetti BB, Dube PN, Shwetha A (2011) Metabolic changes in the freshwater fish Catla catla, under copper cyanide intoxication. Int J Pharm (2) 3:874-879. 
Irving DO, Watson K (1976) Mitochondrial enzymes of tropical fish. Comp Biochem Physiol B 54:81-92. https://doi.org/ 10.1016/0305-0491(76)90061-4.

Ivanina AV, Habinck E, Sokolova IM (2008) Differential sensitivity to cadmium of key mitochondrial enzymes in the Eastern Oyster, Crassostrea virginica Gmelin (Bivalvia: Ostreidae). Comp Biochem Physiol C 148:72-79. https://doi.org/10.1016/j.cbpc.2008.03.009.

Jiang Q, Pan D, Tian J, Jiang G, Yang J, Ren Q (2014) Effect of nitrite stress on gene expression of antioxidant enzymes, heat shock protein 70 , and metabolic enzymes in gill tissue of adult red swamp crayfish, Procambarus clarkii. J Crustacean Biol 34(6): 754-759.

John PJ (2007) Alteration of certain blood parameters of freshwater teleost, Mystus vittatus after chronic exposure to metasystox and sevin. Fish Physiol Biochem 33:15-20. https://doi.org/10.1007/s10695-0069112-7.

King J (1965) The dehydrogenases or oxidoreductases lactate dehydrogenase. In Practical clinic Enzymol London Van Nostrand D Company Ltd: 83-93.

Kumari K, Ranjan N, Sinha RC (2011) Multiple biomarker response in the fish, Labeo rohita due to hexavalent chromium. $2^{\text {nd }}$ International Conference on Biotechnol Food Sci 7: 155-158.

Lu ZM, Hunter T (2018) Metabolic kinases moonlighting as protein kinases. Trends Biochem Sci 43(4):301-310. https://doi.org/10.1016/j.tibs.2018.01.006.N

Martinovic D, Villeneuve DL, Kah MD, Blake LS, Brodin JD, Ankley GT (2009) Hypoxia alters gene expression in the gonads of zebrafish (Danio rerio). Aquat Toxicol 95:258-272.

McKenna MC, Tildon, JT, Stevenson JH, Huang X, Kingwell KG (1995) Regulation of mitochondrial and cytosolic malic enzymes from cultured rat brain astrocytes. Neurochem Res:1491-1501.

Mehler AH, Kornberg A, Grisolia S, Ochoa S (1948) Chemistry and methods of enzyme: desmolases. J Biochem 174:961-977.

Mekkawy IAA, Mahmoud UM, Osman AG, Sayed AH (2010a) Effects of Ultraviolet A on the activity of two metabolic enzymes, DNA damage and lipid peroxidation during early developmental stages of the African catfish, Clarias gariepinus. Fish Physiol Biochem 36:605-626.

Mekkawy IAA, Mahmoud UM, Wassif ET, Naguib M (2010b) Effects of cadmium on some haematological and biochemical characteristics of Oreochromis niloticus (Linnaeus, 1758) dietary supplemented with tomato paste and vitamin E. Fish Physiol Biochem 37:71-84.

Meng ML, Zhen T, Lixia Y, Meize S, Qianyan R, Xiaodan X, Qingzhen M, Rixin W (2016) Effect of high dietary copper on growth, antioxidant and lipid metabolism enzymes of juvenile larger yellow croaker, Larimichthys croceus. Aquacult Rep 3:131-135. https://doi.org/10.1016/j.aqrep.2016.02.001. 
Mevorach M, Giacca A, Aharon Y, Hawkins M, Shamoon H, Rossetti L (1998) Regulation of endogenous glucose production by glucose perse is impaired in type 2 diabetes mellitus. J Clin Invest 102: 744753.Minakami S, Ringleo RC, Singer TP (1962) Respiratory chain linked dihydrodiphosphopyridine nucleotide hydrogenase assay of enzyme in soluble particulate and insoluble preparation. J Biol 237:569579 .

Mommsen TP (2004) Salmon spawning migration and muscle protein metabolism: the August Krogh principle at work. Comp Biochem Phys A 139(3):383-400. https://doi.org/10.1016/j.cbpc.2004.09.018.

Ncibi S, Ben Othman M, Akacha A, Krifi MN, Zourgui L (2008) Opuntia ficus indica extract protects against chlorpyrifos induced damage on mice liver. Food Chem Toxicol 46(2):797-802.

Nivedita G, Vatsal M, Madhuri K, Pushpa S, Smita K, Vaman Rao C (2002) Toxicity study of diethyl phthalate on freshwater fish, Cirrhina mrigala. Ecotoxicol Environ Saf 53:255-258.

http://doi:10.1006/eesa.2002.2212.

Ochoa S (1955a) Malic Enzyme Methods. Enzymol 66:323-325.

Ochoa S (1955b) Isocitrate dehydrogenase methods. Enzymol 66:232-236.

Peal W, Cascarano J, Zweifach BW (1963) Micro determination of cytochrome oxidase in rat tissues by the oxidation on N-phenyl p-phenylene diamine or ascorbic acid. J Histochem Cytochem 11:102-104.

Pelletier D, Dutil JD, Blier P, Guderley H (1994) Relation between growth rate and metabolic organization of white muscle, liver and digestive tract in cod, Gadus morhua. J Comp Physiol B 164:179-190.

Pierron F, Bourret V, St-Cyr J, Campbell PGC, Bernatchez L, Couture P (2009) Transcriptional responses to environmental metal exposure in wild yellow perch (Perca flavescens) collected in lakes with differing environmental metal concentrations (Cd, $\mathrm{Cu}, \mathrm{Ni})$. Ecotoxicol 18:620-631.

Rao JV, Rai CHS, Kavitha P, Rao RN, Mahavendra SS (2003) Toxicity of chlorpyrifos to the fish, Oreochromis mossambicus. Bull Environ Contam Toxicol 70:285-292.

Rivero CLG, Barbosa AC, Ferreira MN, Dorea JG, Grisolia CK (2008) Evaluation of genotoxicity and effects on reproduction of nonylphenol in Oreochromis niloticus (Pisces: cichlidae). Ecotoxicol 17:732737. https://doi.org/10.1007/s10646-008-0222-0.

Sastry KV, Gupta PK (1980) Alterations in the activities of a few dehydrogenases in the digestive system of 2 teleost fishes exposed to lead nitrate. Ecotoxicol Environ Saf 4:232-239. https://doi.org/10.1016/0147-6513 (80)90025-1.

Saito T, Kato K, Yokogawa Y, Nishida M, Yamashita N (2004) Detoxification of bisphenol A and nonylphenol by purified extracellular laccase from a fungus isolated from soil. J Bio sci Bioeng 98(1):6466. https://doi.org/10.1016/s1389-1723 (04)70243-1. 
Sayed AH, Mahmoud UM, Mekkawy IAA, (2012) Reproductive biomarkers to identify endocrine disruption in Clarias gariepinus exposed to 4-nonylphenol. Ecotoxicol Environ Safe 78:310319. https://doi.org/10.1016/j.ecoenv.2011.11.041.

Sazanov LA (2014) The mechanism of coupling between electron transfer and proton translocation in respiratory complex I. J Bioenerg Biomembr 46:247-253.

Singh K, Sharma B (1998) Carbofuran-induced biochemical changes in Clarias batrachus. Pest Manag Sci 53(4):285-290. https://doi.org/10.1002/ (SICI) 1096-9063(199808)53:4<285::AID-PS771>3.0.C0;2-0.

Slater EC, Bonner WD (1952) The effect of fluoride on succinic oxidase system. J Biochem 52(2):185-196. https://doi.org/10.1042/bj0520185.

Soares AA, Guieysse B, Jefferson B, Cartmell E, Lester JN (2008) Nonylphenol in the environment: A critical review on occurrence, fate, toxicity and treatment in wastewaters. Environ Int 34(7):10331049. https://doi.org/10.1016/j.envint.2008.01.004.

Sreedevi NV, Chitra, KC (2014) Biochemical and genotoxic effects of octylphenol in hepato-mitochondrial fractions of freshwater fish, Oreochromis mossambicus...Cell Tissue Res 14(2):4211-4218.

Suneetha K (2012) Effects of endosulfan and fenvalerate on carbohydrate metabolism of the freshwater fish, Labeo rohita (Hamilton). Int J Pharm Pharm Sci 4:262-268.

Sunny F, Annamma J, Oommen OV (2003) Genomic effect of glucocorticoids on enzymes of intermediary metabolism in Oreochromis mossambicus. Endocr Res 29:119-131.

Swanson MA (1955) Glucose-6-phosphatase from liver. Meth Enzymol 2:541543. https://doi.org/10.1016/s0076-6879 (55)02247-7.

Tello D, Balsa E, Acosta-Iborra B, Fuertes-Yebra E, Elorza A, Ordonez A, Corral-Escariz M, Soro I, LopezBernardo E, Perales-Clemente E, Martinez-Ruiz A, Enriquez JA, Aragones J, Cadenas S, Landazuri MO (2011) Induction of the mitochondrial NDUFA4L2 protein by HIF-1 a decreases oxygen consumption by inhibiting complex I activity. Cell Metab 14:768-779.

Tiwari S, Singh A (2009) Changes in some biochemical parameters in the liver and muscle of Colisa fasciatus due to toxicity of ethanolic extract of Nerium indicum mill (Lal Kaner) latex. Nat Prod Rad $8(1): 48-54$.

Tiwari S, Tiwari R, Singh A (2012) Impact of cypermethrin on fingerlings of common edible carp (Labeo rohita). Sci World J (1):291395. https://doi.org/10.1100/2012/291395.

Tsuda T, Takino A, Kojima M, Harada K, Muraki T, Tsuji M (2000) 4-Nonylphenols and 4-terc-octylphenol in water and fish from rivers flowing into Lake Biwa. Chemosphere 41(5):757-

762. https://doi.org/10.1016/S0045-6535 (99)00465-8. 
Vineet Kumar K, Patel R, David M (2008) Behaviour and respiratory dysfunction as an index of Malathion toxicity in freshwater fish, Labeo rohita. Turk J Fish Aquat Sc 8:233-237.

Vutukuru SS (2005) Acute effects of hexavalent chromium on survival, oxygen consumption, hematological parameters and some biochemical profiles of the Indian major carp, Labeo rohita. Int J Environ Res Public Health 2(3):456-462. https://doi.org/10.3390/ijerph2005030010.

Woo S, Denis V, Won H, Shin K, Lee G, Lee TK, Yum S (2013) Expressions of oxidative stress-related genes and antioxidant enzyme activities in Mytilus galloprovincialis (Bivalvia, Mollusca) exposed to hypoxia, Zool Stud 52(1):15.

Xueji L, Liting Z, Yiping N, Aiqing W, Mingjiang H, Yao L, Chengjiao H, Jianmei W, Bin C, Lijun F, Jian T, Xing T, Shasha T, Hailin T (2017) Nonylphenol induces pancreatic damage in rats through mitochondrial dysfunction and oxidative stress. Toxicol Res (Camb) 6(3):353-360.

https://doi.org/10.1039/C6TX00450D

Yang M, Qiu W, Chen B, Chen J, Liu S, Wu M, Wang KJ (2015) The in vitro immune modulatory effect of bisphenol $A$ on fish macrophages via estrogen receptor $a$ and nuclear factor_k B signaling. Environ Sci Technol 49:1888-1895. https://doi.org/ 10.1021/es505163v.

Yaron Z, Gur G, Melamed P, Rosenfeld H, Elizur A, Levavi-Sivan B (2003) Regulation of fish gonadotropins. Int Rev Cytol 225:131-185.

Young SJ, Dowman A, Cowell DC (1999) The detection of pentachlorophenol by its inhibitory effectiveness on lactate dehydrogenase of rabbit muscle and bovine heart. J Pest Biochem Physiol 64:18.

Zhang X, Yang S, Chen J, Su Z (2019) Unraveling the regulation of hepatic gluconeogenesis. Front Endocrinol (Lausanne) 24(9):802. https://doi.org/10.3389/fendo.2018.00802.

\section{Figures}




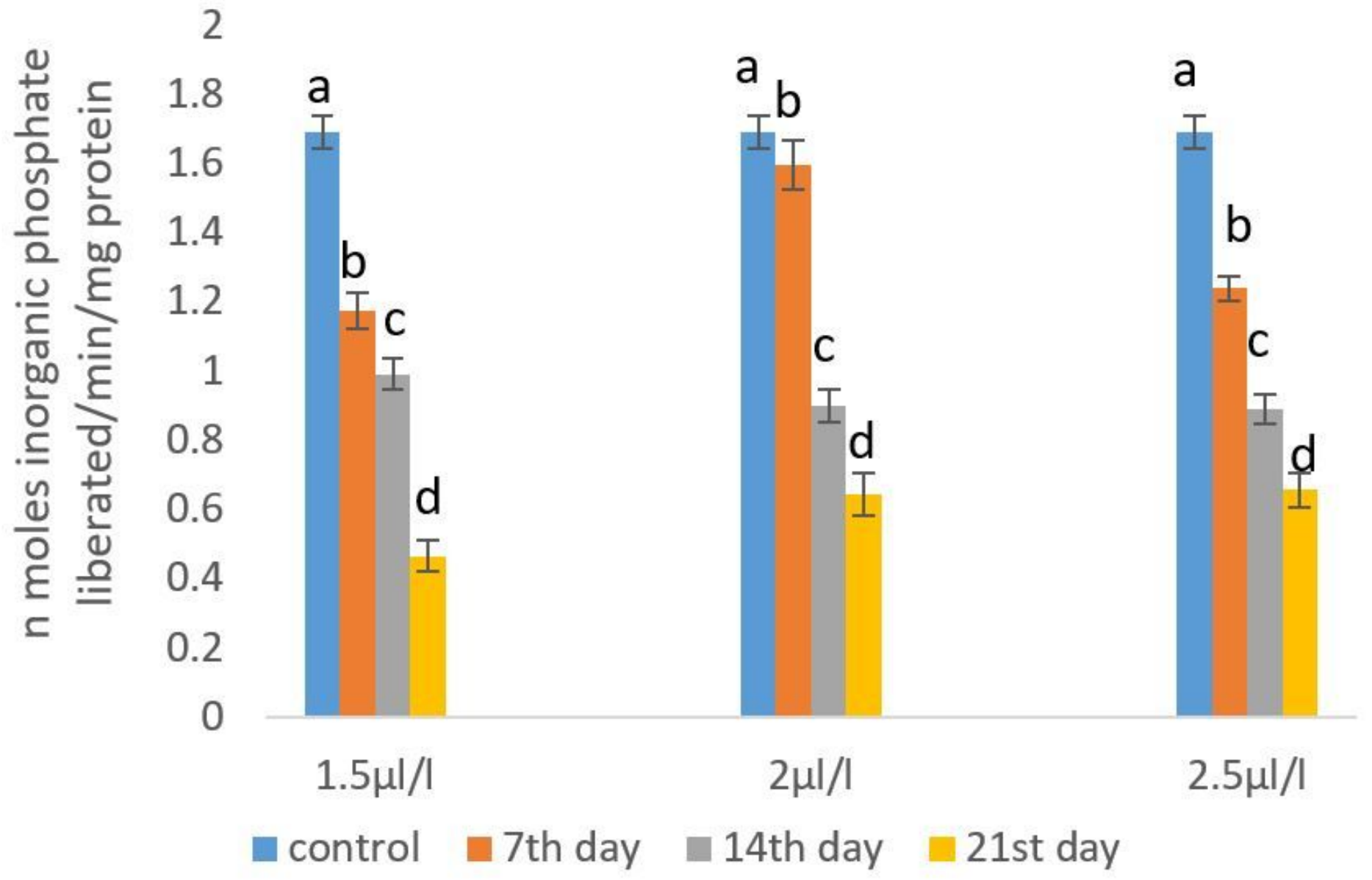

Figure 1

Effect of 4-NP $(1.5 \mu \mathrm{l} / \mathrm{I}, 2 \mu \mathrm{l} / \mathrm{I}$ and $2.5 \mu \mathrm{l} / \mathrm{I})$ on G6P04ase activity in the liver of L.rohita for control, 7, 14 and 21 days. Each bar is mean \pm SEM for six fish. Mean values of different superscript letters $(a, b, c$ and $d)$ were significantly different $(p<0.05)$. 


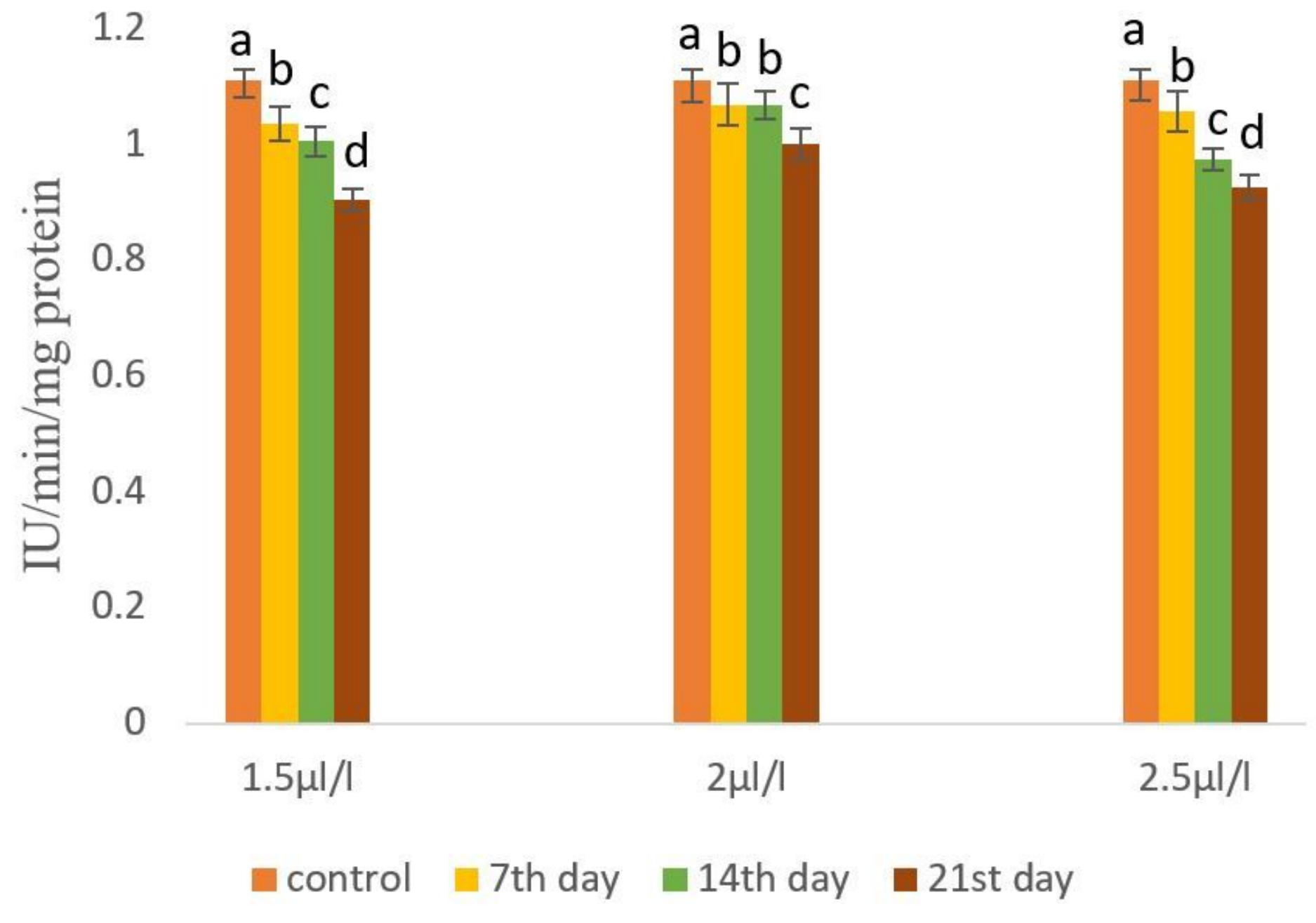

Figure 2

Effect of 4-NP $(1.5 \mu \mathrm{l} / \mathrm{I}, 2 \mu \mathrm{l} / \mathrm{I}$ and $2.5 \mu \mathrm{l} / \mathrm{I})$ on LDH activity in the liver of L.rohita for control, 7, 14 and 21 days. Each bar is mean \pm SEM for six fish. Mean values of different superscript letters $(a, b, c$ and $d)$ were significantly different $(p<0.05)$. 
0.3

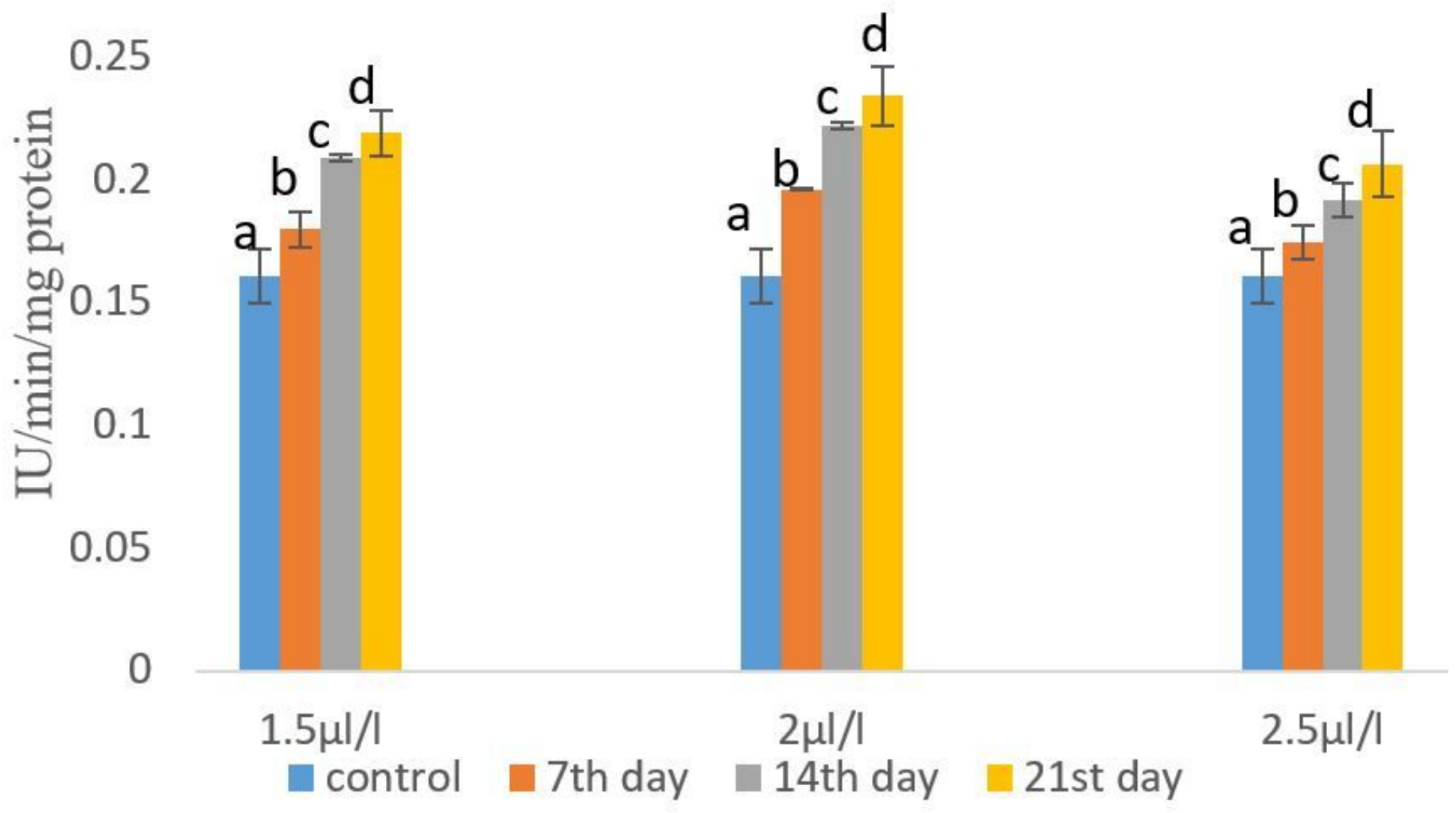

Figure 3

Effect of 4-NP $(1.5 \mu \mathrm{l} / \mathrm{l}, 2 \mu \mathrm{l} / \mathrm{I}$ and $2.5 \mu \mathrm{l} / \mathrm{I})$ on cME activity in the liver of L.rohita for control, 7,14 and 21 days. Each bar is mean \pm SEM for six fish. Mean values of different superscript letters $(a, b, c$ and $d)$ were significantly different $(p<0.05)$. 


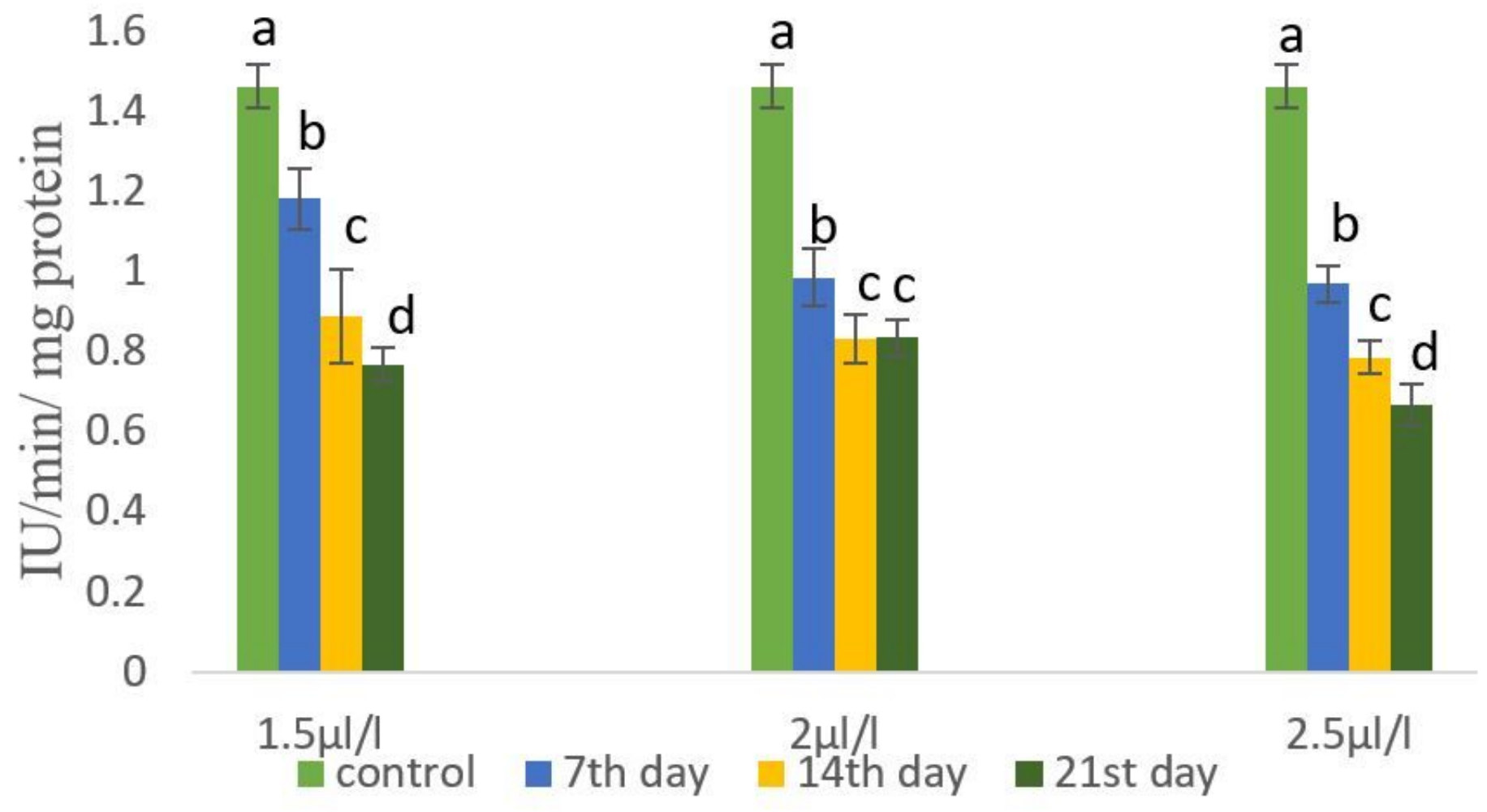

Figure 4

Effect of 4-NP $(1.5 \mu \mathrm{l} / \mathrm{I}, 2 \mu \mathrm{l} / \mathrm{I}$ and $2.5 \mu \mathrm{l} / \mathrm{I})$ on ICDH activity in the liver of L.rohita for control, 7,14 and 21 days. Each bar is mean \pm SEM for six fish. Mean values of different superscript letters $(a, b, c$ and $d)$ were significantly different $(p<0.05)$. 


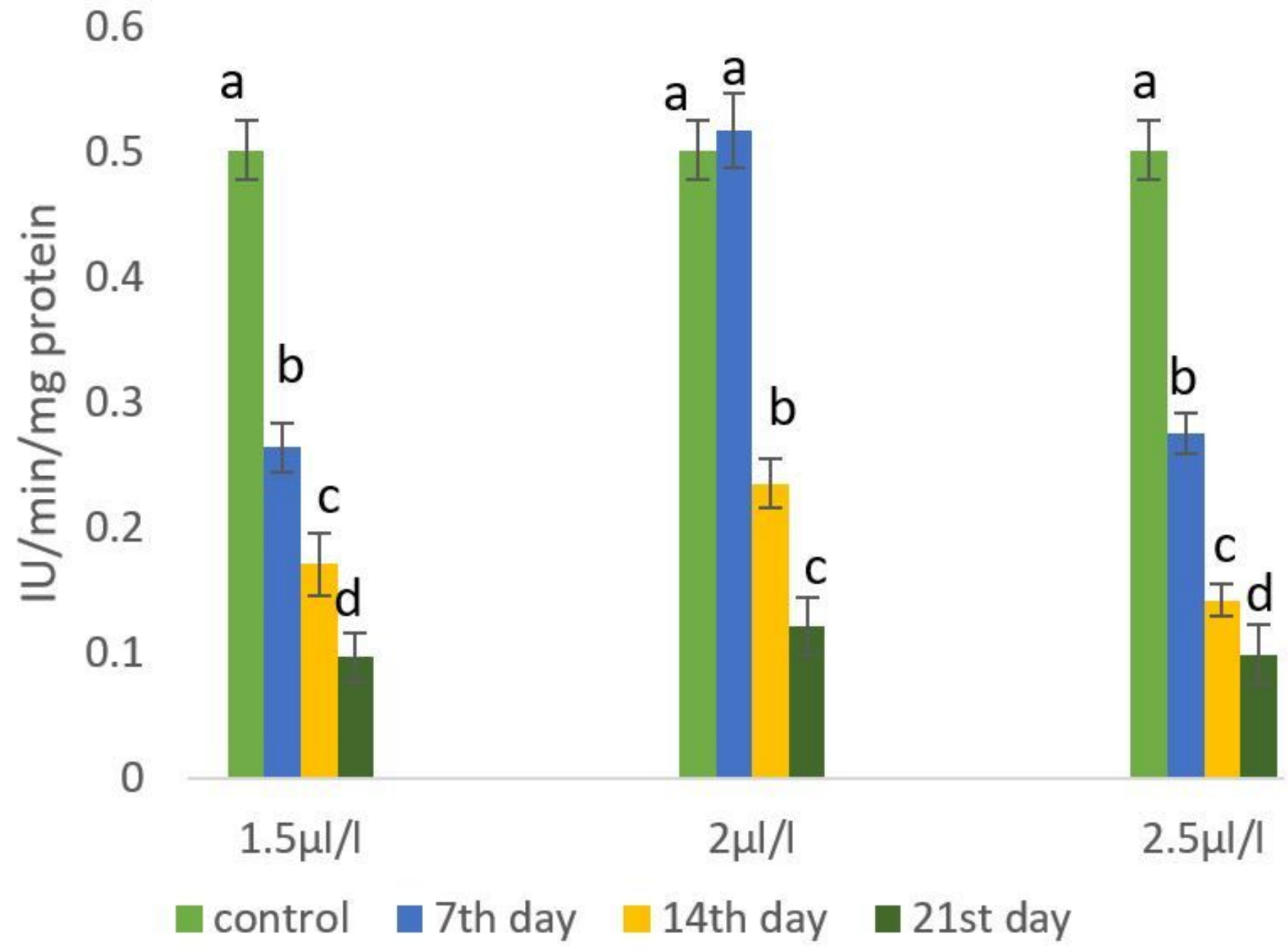

Figure 5

Effect of 4-NP $(1.5 \mu \mathrm{l} / \mathrm{I}, 2 \mu \mathrm{l} / \mathrm{I}$ and $2.5 \mu \mathrm{l} / \mathrm{I})$ on MDH activity in the liver of L.rohita for control, 7,14 and 21 days. Each bar is mean \pm SEM for six fish. Mean values of different superscript letters $(a, b, c$ and d) were significantly different $(p<0.05)$. 


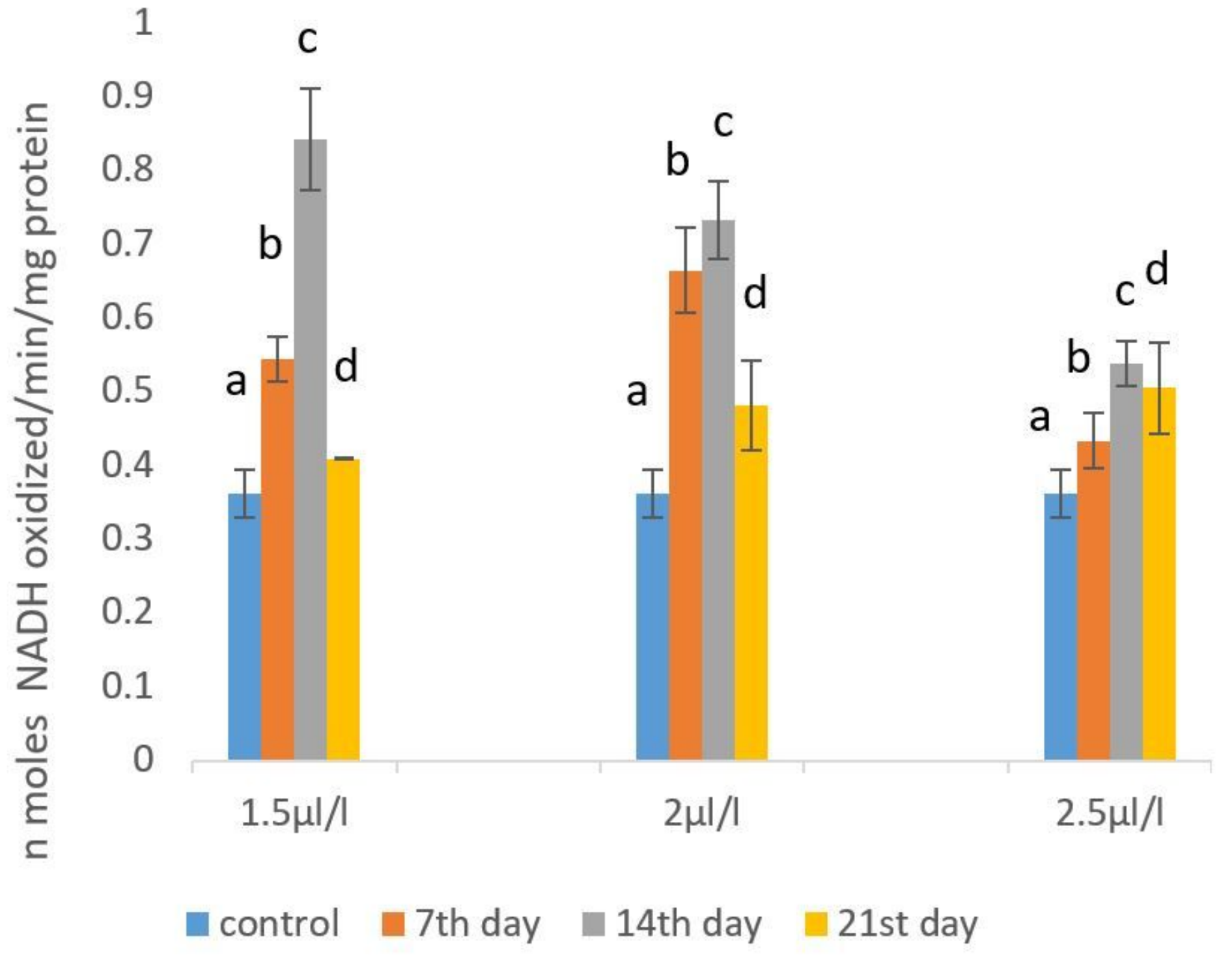

Figure 6

Effect of 4-NP $(1.5 \mu \mathrm{l} / \mathrm{l}, 2 \mu \mathrm{l} / \mathrm{I}$ and $2.5 \mu \mathrm{l} / \mathrm{I})$ on NADH dehydrogenase activity in the liver of L.rohita for control, 7, 14 and 21days. Each bar is mean \pm SEM for six fish. Mean values of different superscript letters $(a, b, c$ and $d)$ were significantly different $(p<0.05)$. 


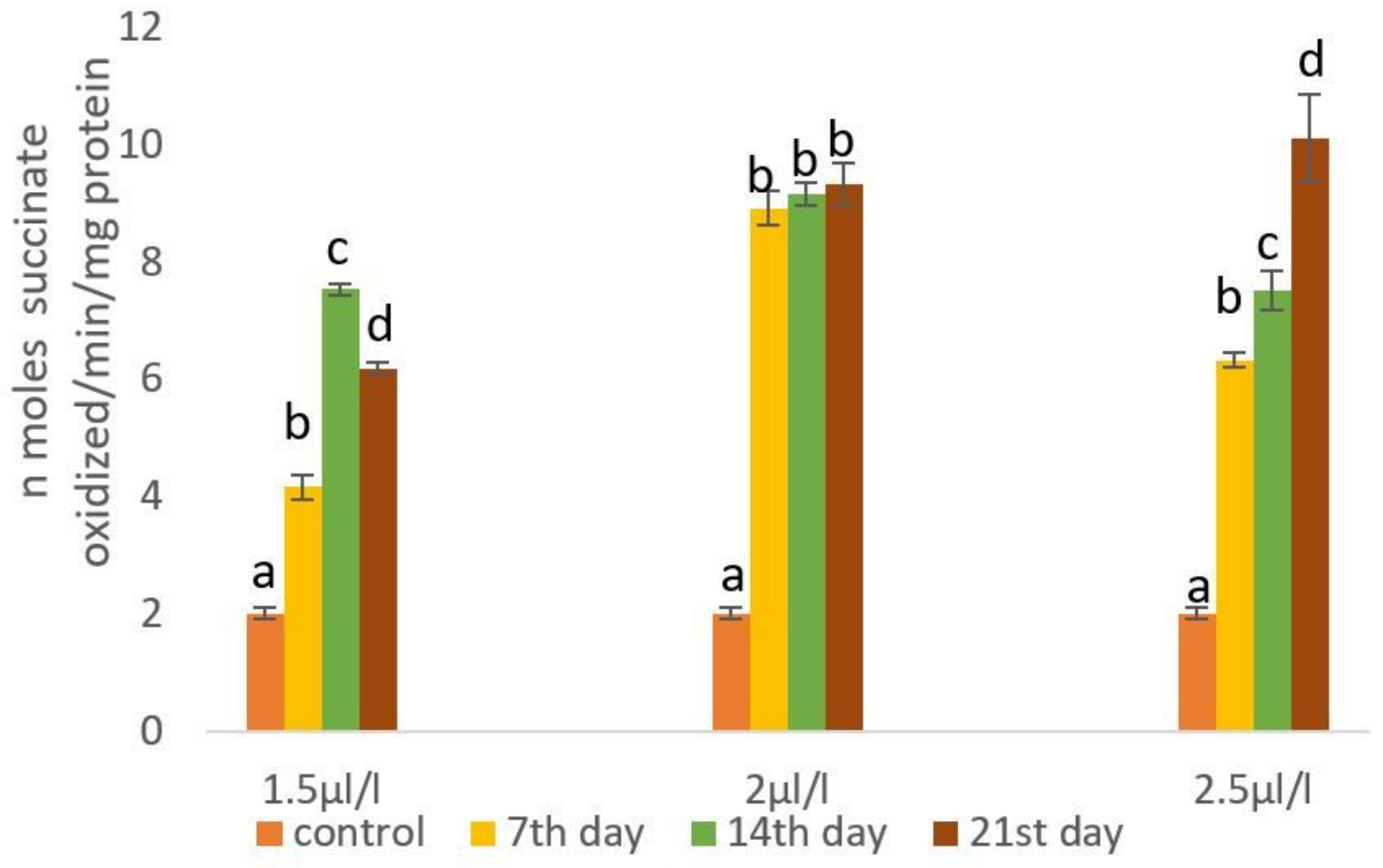

Figure 7

Effect of 4-NP $(1.5 \mu \mathrm{l} / \mathrm{I}, 2 \mu \mathrm{l} / \mathrm{I}$ and $2.5 \mu \mathrm{l} / \mathrm{I})$ on SDH activity in the liver of L.rohita for control, 7, 14 and 21 days. Each bar is mean \pm SEM for six fish. Mean values of different superscript letters $(a, b, c$ and $d)$ were significantly different $(p<0.05)$. 


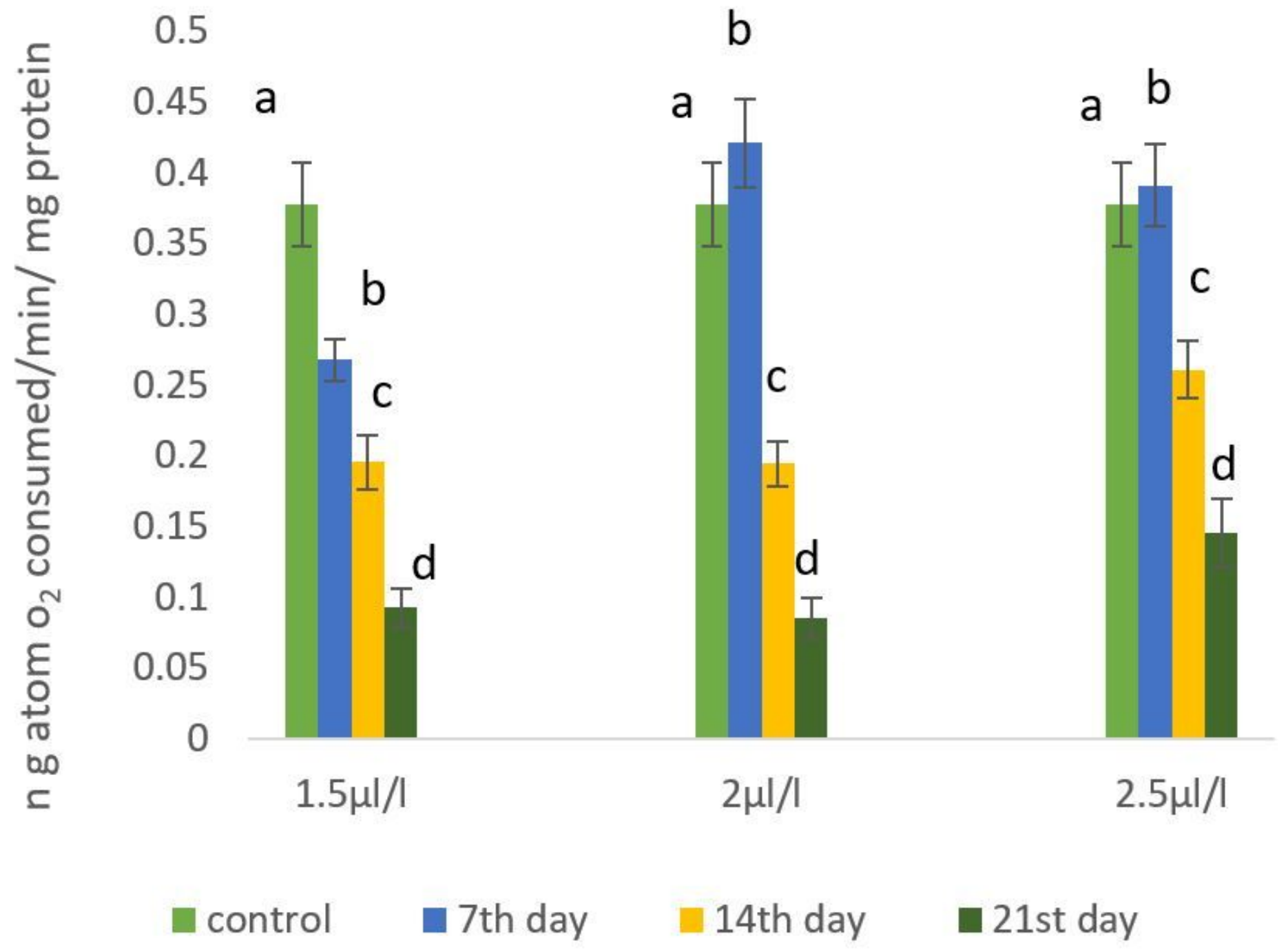

Figure 8

Effect of 4-NP $(1.5 \mu \mathrm{l} / \mathrm{I}, 2 \mu \mathrm{l} / \mathrm{I}$ and $2.5 \mu \mathrm{l} / \mathrm{I})$ on CCO activity in the liver of L.rohita for control, 7, 14 and 21 days. Each bar is mean \pm SEM for six fish. Mean values of different superscript letters $(a, b, c$ and $d)$ were significantly different $(p<0.05)$. 